\title{
České a německé hudební spolky v Olomouci v letech 1918 až 1939
}

\author{
Eva Vičarová
}

Výzkum dějin hudby na Moravě a v Olomouci náleží již po dlouhou dobu k badatelskému zaměření členů Katedry muzikologie Filozofické fakulty Univerzity Palackého v Olomouci. Letos začínají dvě členky katedry pracovat na tématu, které dosud nebylo v regionální hudební historiografii zpracováno, přestože se jedná o významný a svým způsobem i jedinečný fenomén olomoucké a moravské hudební kultury.

Hlavní řešitelkou projektu s názvem České a německé hudební spolky v Olomouci v letech 1918 až 1939 je Eva Vičarová, spoluřešitelkou Ingrid Silná. Obě hodlají při své práci využít nejen vědecké zkušenosti získané například při práci na výzkumném záměru „Morava a svět: Umění v otevřeném multikulturním prostoru“ a na syntetické publikaci Hudba v Olomouci 1945-1912, ale rovněž zúročit svou znalost regionálních archivních fondů i informačních zdrojů.

Cílem čtyřletého projektu, jenž má vyústit do několika studií a dvou monografií, je zmapovat historii a funkci českých a německých hudebních spolků působících v období 1918-1939 v Olomouci, zasadit jejich činnost do širšího historického a kulturního kontextu a zhodnotit jejich význam pro rozvoj uměleckého klimatu Olomouce v období první (resp. druhé) republiky. Hudební události (například koncertní vystoupení a uváděné skladby) budou vyhodnoceny z hlediska kvantitativního (jako jevy typické resp. standardní z hlediska celostátního či naopak jako jevy regionálně příznačné či specifické), ale i kvalitativního (například olomoucká hostování význačných koncertních umělců a včasná uvedení významných skladeb v souladu s mezinárodními hudebními trendy př́slušné doby).

V období první (resp. druhé) Československé republiky (1918-1939), vyznačujícím se relativně př́znnivou politickou a ekonomickou situací, byl stabilizován veřejný hudební život a dovršen proces rozštěpení hudební kultury na kulturu českou a německou, odstartoval se přerod dalších vrstev amatérské a poloamatérské hudební činnosti ve sféru hudby profesionální a v neposlední řadě se polarizovaly regionální formy tradiční a moderní populární hudby. Hudební spolky přispívaly k rozvoji hudební kultury a hudebnosti obyvatelstva prostřednictvím organizovaných veřejných (koncertních a zábavních) vystoupení i seberealizace svých členů. 
Určujícími se staly hudební aktivity spolků českých, nicméně i po roce 1918 vyvíjely v Olomouci své velmi pozoruhodné produkce tradiční spolky německé, jako byly např. Musikverein (působil v letech 1851 až 1944), Männergesangverein (1860-1946), Verein Olmützer Zitherclub (1880-1946), Gesangverein in Neu- und Greinergasse (1888-?), Deutsche Damen Singverein (1888-1946), Olmützer Musikerbund (1900-1924), Gauverband der deutschen Gesangvereine von Olmütz und Umgebung (1910-1927) a Deutscher Volksgesangverein für Olmütz und Umgebung (1912-1946).

Vlivem společenského, politického, ale i hudebního vývoje byly německé hudební spolky stále výrazněji konfrontovány s již zavedenými, rozvijejícími se či nově vznikajícími hudebními spolky českými. Z nich je nutno na prvním místě jmenovat Hudební spolek Žerotín (založen v roce 1880), jenž zasahoval do místní kultury nejen prostřednictvím své hudební školy (1888), smíšeného sborového tělesa a amatérského orchestru, ale který stál jako ambiciózní instituce po první světové válce rovněž u zrodu pravidelného koncertního života (Filharmonie Žerotína působila v letech 1925-1945 jako předstupeň poválečné Moravské filharmonie Olomouc) a stálé organizace komorních koncertů (Komorní odbor Žerotína byl založen v roce 1928) i vokálních těles Dvanáctka, resp. Šestnáctka a Nešvera.

V Adresári Velké Olomouce z let 1928 a 1938 evidujeme vedle již zmíněných institucí tyto další hudební spolky: Pěvecký kroužek Československé obce legionářské (založen v roce 1922), Lípa - hudební spolek v Olomouci, Místní odbočka odborového sdružení hudebníků v republice Čsl. v Olomouci, Pěvecko-hudební kroužek čsl. Železničních a poštovních zřízenců pro Olomouc a okolí (1921), Unie čsl. hudebníků, odbočka pro Olomouc a okolí (1921), Čtenářsko-pěvecký spolek Jaroslav Černovír, Klášterní Hradisko, Hudební spolek Olomouc-Černovír, Místní odbočka Kruhu čsl. skladatelů a spisovatelů populární hudby „Kapo“, se sídlem v Olomouci, II. Pěvecká župa hanácká Tovačovského v Olomouci, Pěvecko-dramatický a hudební spolek „Čechoslovák“ pro Olomouc-Hodolany a okolí se sídlem v Olomouci-Hodolanech, Sbor tamburašů „Triglav“ pro Olomouc-Hodolany se sídlem v Olomouci-Hodolanech a Gesangverein in Olmütz-Neretein.

Je zřejmé, že hudba byla součástí aktivit i následujících uměleckých spolků: Jednoty divadelních ochotníků besedních (1872), Občanské besedy (1872), Spolku Klub přátel umění v Olomouci (1918), Družiny literární a umělecké pro ČSR se sídlem v Olomouci, „Fora“ - společnosti přátel současné kultury, sídlem v Olomouci, Dramatického sdružení „Studio“ v Olomouci, Vzdělávacího a zábavního spolku Jeroným pro Olomouc-Bělidla, Chválkovice, Pavlovičky a Týneček, v Olomouci-Pavlovičkách, Vzdělávacího a zábavního spolku Čechoslovák pro Bělidla, Pavlovičky, Chválkovice a Týneček v Olomouci-Bělidlech, Vzdělávacího a zábavního spolku Pravoslavná beseda v Olomouci, sídlem v Olomouci, Deutsche dramatische Gesellsaft Olmütz, Bezirk-Verbund Olmütz der Deutscher Kulturverbandes se sídlem v Olomouci (1921), Deutscher Theaterverband in Olmütz (1913), Gesellschaft der Kunstfreunde in Olmütz (1910), Deutscher Kulturverband, Ortsgruppe Olmütz-Neretein či Deutscher Kulturverband Olmütz-Neugasse-, Beamtenviertel, Hauptsitz in Reichenberg. 
Nejdůležitějším zdrojem pramenů se stanou fondy Státního okresního archivu Olomouc a Zemského archivu v Opavě, pobočka Olomouc. Bude rovněž pracováno s dobovým tiskem a informacemi zprostředkovanými v odborné literatuře. 